\title{
Youth empowerment through entrepreneurial development in Nigeria
}

\author{
David Ifeanyi Okoli ${ }^{1}$, Emmanuel Ifeanyi Okoli ${ }^{2}$ \\ ${ }^{1}$ Federal College of Education (Technical), Umunze, Anambra State, Nigeria \\ ${ }^{2}$ Madonna University, Okija, Anambra State, Nigeria
}

\begin{abstract}
Entrepreneurial development is a field that saddles its recipients with skills on how to be employable and useful to themselves and the society at large. In this paper, the emphasis is on youth empowerment which is orchestrated by the prevailing unemployment of our youths after higher education, yet each year all the higher institutions in the country keep on churning out graduates in thousands into the labour market for jobs that are non-existent. Hence the need for entrepreneurial development as a way of equipping them with the necessary skills that will enable them start up something on their own. The paper amongst others looked at the objectives of entrepreneurship development, support organizations for entrepreneurship in Nigeria, tips for entrepreneurship development, implications for entrepreneurship development on youth empowerment. More so, certain recommendations were made.
\end{abstract}

Keywords: Entrepreneurial development; higher education; unemployment

\section{INTRODUCTION}

Nigeria faces a major problem of graduate unemployment (Ojeagu, 2011). Young men and women leave the Universities, Polytechnics and Colleges of Education every year with little hope of securing jobs (Inegbenebor, 2005). He noted that the most significant factor that has complicated the problem of graduate unemployment is the slow growth of the economy. Between 1995 and 2002, GDP grew at an average of only $3.3 \%$ per annum (OECD, 2012). Thus, the capacity of the economy to absorb the products of an over expanding tertiary institutions is severely limited. The Nigeria government is very worried on the increasing unemployment rate, poverty and generally, bad economic condition in the country (Garba, 2010).

Thus under the National Economic Empowerment and Development Strategy (NEEDS) Nigeria seek to create an economy in which numerous, large indigenous enterprises engage in industrial merchandizing, financing and servicing activities to create wealth, generate employment and eradicate poverty. Poverty, unemployment and corruption are major national problems in Nigeria (Akpan, 2011). On the basis of 2008 GDP nominal of \$115 billion, Nigeria ranked $48^{\text {th }}$ in the world. This translated to GDP per capita income of $\$ 1.213$ which made Nigeria stand at $165^{\text {th }}$ position in the world, and 33 out of 44 countries in sub-Saharan Africa yet we answer giant of Africa. The Federal Office of Statistics (FOS), estimates that about $70 \%$ of Nigerians live below the poverty line. The World Bank in Global Economic Prospects 2010, predicted $4.8 \%$ growth in GDP for Nigeria this year and $5.1 \%$ next year as 
against $4.3 \%$ last year. The population grows at $2.38 \%$ per annum while industrial output grows at $2.40 \%$ per annum. According to UNIDO representative in West Africa, Matsushita (2008), Nigeria's vision 20:2020 is not achievable at the current rate of industrialization in the country.

The blessing of national endowment has not meant much for most Nigerians, even though the country ranks $6^{\text {th }}$ in world crude oil production and there is abundance of every conceivable natural resource including arable land, water resources, good weather, mineral deposits and a large population, yet Nigerians are among the poorest in the world (Akpan, 2011). Life expectancy is a mere 46 years, infant mortality is 97 per 1000, maternal mortality is 704 per 100,000 , only about half the population have access to portable drinking water, adult literacy is $49 \%$, about $24 \%$ of children of primary school age do not attend school. The inability of the economy to convert these abundant natural resources into goods and services has meant severe suffering for the majority of Nigerians in the midst of plenty. In an attempt to escape this, many talented Nigerians have migrated to other countries with far less favourable environment resource-wise.

According to the Norwegian Agency for Development Cooperation (2010), in many developing countries persons with general secondary and higher education experience unemployment. In the same vein, Nwagwu (2004) noted that many Nigerian youths are wallowing in abject penury while many women and children are disease prone and dehumanized as a result of poverty and unemployment. She lamented that government often cushions the effect of poverty on vulnerable groups by establishing vocational and technical schools with the objectives to impart employability skills and competences to youths, school leavers, women and others who would be self-reliant and enterprising. This calls to mind the need for entrepreneurial development. In most cases why unemployment has subsisted is that most of the products of our institutions of higher learning are half baked and unusable by users of the products. Our curriculum are not related to the needs of the employers, hence graduates are subjected to period of extra training before they are accepted as workers in a company or system. However, Oviawe and Anavberokha (2008) opine that if our graduates are properly harnessed through entrepreneurship skills, Nigeria will be transformed technologically, economically, industrially and socio-politically. By these attributes our youths will be adequately empowered to face the world of work and stand tall in the comity of nations.

\section{CONCEPT OF ENTREPRENEURSHIP}

The term entrepreneurship is derived from a French word "entrepreneur" meaning one who undertakes tasks in a production process. It could also be defined in terms of specific functions which the entrepreneur performs or in terms of characteristics or activities generally associated with the entrepreneur. The concept of entrepreneurship has been explained by various authors in various ways. However in all, the basic issues remain constant. For instance entrepreneurship has been defined as:

(a) The willingness and the ability of an individual to seek out investment opportunities in an environment and be able to establish and run an enterprise successfully based on the identified opportunities (Gana, 2008).

(b) What occurs when an individual develops a new venture or a new approach to an old business or idea or a unique way of giving the market place a product or service by using resources in a new way under conditions or risk (Ihekwoba, 2007). 
(c) A clear manifestation of effective manipulation of human intelligence as demonstrated in creative performance (Iheonunekwu, 2003). It seeks to find out how best graduates can convert their education to intellectually productive ventures in order to bring out the best in an individual.

(d) It involves risking financial, material and human resources in a new way in the course of creating a new business concept or opportunity within an existing firm (Steinhoff and Burges, 2003)

(e) Creating and building something of value from practically nothing or creation and distribution of something of value and of benefits to individuals, groups, organizations and society (Timmons, 2007).

(f) The dynamic process of creating incremental wealth (Hisrich and Peters, 2007). The wealth created by individuals who assure the major risks in terms of equity, time and/or career commitment or provide value for some product or service. The product or service may or may not be new or unique but value must somehow be infused by the entrepreneur. This is usually coupled with financial, psychic and social risks with resultant rewards of monetary and personal satisfaction and independence.

(g) The willingness and ability of an individual to seek out investment opportunities in an environment and be able to establish and run an enterprise successfully based on the identified opportunities (Igbo, 2004).

\section{MAJOR OBJECTIVES OF ENTREPRENEURSHIP EDUCATION/DEVELOPMENT}

Oborah (2006) outlined the objectives of entrepreneurship development to include the following:

1. To provide meaningful education for the youths, which could make them self-reliant and subsequently encourage them to derive profit and be self dependent.

2. To provide small and medium sized companies with the opportunities to receive qualified graduates who will receive training and tutoring in the skills relevant to the management of the small business centers.

3. To provide graduates with the training and support necessary to help them establish a career in small and medium sized businesses.

4. To provide graduates with training in skills that will make them meet the manpower needs of the society

5. To provide graduates with enough training that will make them creative and innovative in identifying new business opportunities.

6. To provide graduates with enough training in risk management to make uncertainty almost possible and easy

7. To stimulate industrial and economic growth of rural and less developed areas.

Furthermore, Atakpa, (2011) submits that one of the strategic objectives of entrepreneurship Education is to produce graduates of international standard with appropriate knowledge and skills in their field of study who will be highly employable and able to employ themselves. 


\section{CREATING ENTREPRENEURIAL SKILLS IN NIGERIAN YOUTHS}

Akpoveta and Agbomah (2009) said that the increasing incidence of youth unemployment particularly, graduate unemployment in Nigeria has been associated with existing weaknesses in the nations' educational system which places more emphasis on paper qualification than functional or pragmatic education. This result in production of unemployable graduates not suited for the labour market. Damuchi (2001) captured the present manpower-labour market discrepancy scenario, he observed that the Nigeria educational system has failed to produce workers with adequate technical, cognitive and attitudinal skills required to meet the labour market demands.

While taking a look at the current happenings, majority of graduates of higher institutions in Nigeria lack the expected technical communication and human relations as well as entrepreneurial skills required for self reliance and self employment due to the non functional education to which they are exposed. In order to correct this anomaly and tackle the consequences of mass youth unemployment, the Federal Government of Nigeria in 1986 introduced the "Small Scale Industry and Graduate Employment Scheme under the National Directorate of Employment (NDE), (Akpoveta and Agbomah, 2009). They further stated that skills acquisition workshops and seminars were organized for unemployed graduates who are practically re-trained on the technicalities of starting and running small scale business (self employed) such as the production of soap, detergents and cosmetic, poultry, fish farming website design and network marketing, mobile phone repairs and maintenance etc. NDE guaranteed loans to the beneficiaries to start projects of their choice after training as well becoming bosses of their own business (Self actualization).

Ideally, the scheme would have been a potent instrument for job creation and gradual reduction of graduate unemployment rate but due to certain weakness which were empirically evaluated, which need to be corrected in order to sustain the efforts made by the government. Such weaknesses includes poor financial management of their businesses, poor marketing strategies, lack of good planning and good management, lack of will power and determination, lack of cooperative relations among beneficiaries etc. These weaknesses outlined are not unexpected, but only portray the missing link which is needed to compliment the skill acquisition schemes with entrepreneurship development programmes, in order to properly position beneficiaries for successful management of their small scale businesses. (Akpoveta and Agboma, 2009).

\section{SUPPORT ORGANIZATIONS/DEVELOPMENT INSTITUTION FOR ENTREPRENEURSHIP IN NIGERIA}

It has to be said that various programmes and institutions have been initiated in the past by both military and civilian administrations in the country aimed at functional entrepreneurship, skill acquisition, job creation, poverty reduction, wealth creation, food adequacy, reduction of unemployment, youth empowerment and reduction of crime in the society. The success rate of these programmes could be best imagined than discussed. However, they have become historical records with lessons to draw from them. Some of them include Operation Feed the Nation (OFN), Green Revolution, National Directorate of Employment (NDE), Directorate of Foods, Roads, and Rural Infrastructure (DFRRI), Oil Minerals Producing Areas Development Commission (OMPADEC), Mass Transit Programmes, National Economic Empowerment and Development Strategy (NEEDS), The 
New Partnership for African Development (NEPAD), Industrial Training Fund (ITF), The Education Tax Fund (ETF) (Now TETFund) Cooperate Affairs Commission (CAC), The Industrial Development Centres (IDCs), National Open Apprenticeship Scheme (NOAS), Waste to Wealth Scheme (WWS), Small Scale Industries and Graduate Employment Programme (SSI/GEP), Agricultural Sector Employment Programme (ASEP) National Economic Reconstruction Fund (NERFUND) Peoples Bank of Nigeria (PBN), Micro Finance Banks (MFB) etc.

The organizations and programmes stated above have been established by both the federal and state governments. The CAC performs the registration of entrepreneurship business name and other related roles, for private individuals and groups. The Industrial Development Centres (IDC) aim at promoting and developing entrepreneurs in Nigeria, this is achieved through training, technical advice on machinery and equipment, manager advice in the area of marketing, finance, credit arrangements, preparation of feasibility studies or business plan, creating training opportunities for the unemployed youths in the society, encouraging the conversion of waste products to useful sellable products, providing funds and loans to entrepreneurs after training. These organizations and programmes were in existence to combat mass unemployment, development of work programmes for a pool of entrepreneurs, encouraging self-employment, creating employment for others, up-grading the social status of youths in Nigeria, offering consultancy services (usually to advice on problem areas) at implementation stages of development to other non-economic ventures.

\section{TIPS FOR ENTREPRENEURIAL DEVELOPMENT AND SUCCESS}

The following are the top 5 steps for entrepreneurial development and success as postulated by Branson (2010)

1) The people factor skill: This is the basis of many entrepreneurial successes and because many business leaders discount it, innumerable failures occur. While the current thinking in business schools holds that someone with an idea needs to succeed through focus, clarity and good business plan. It is obvious that bringing together a great team that is united by strong motivation, determination and bravery is much more important. It should be inculcated in pupils/students from the scratch as a skill on how to assemble great management team that have a vision, passion and a real sense of ownership.

2) Politeness Skill: A successful business isn't the product or service it sells, its supply chain or its corporate culture. It is a group or people bound together by a common purpose and vision. The best designed business plan will come to nothing if it is not carried out by an enthusiastic and passionate staff. This is especially true when things go slightly wrong, a friendly and proactive team can often win people round, averting a potential disaster or even turning it to your benefit.

3) Appreciation skills: Always look for the best in your people. Lavish praises for any success recorded. Never criticize, rather focus on mistakes as to make it better next time, catch someone doing something right every day. If this culture of fostering employee development through praise and recognition starts at the top, it will go far toward stamping out the employee fear of failure that can stunt a business, particularly in its early days. When mistakes happen which is inevitable always take the position that you have to learn from them and try not to dwell on what went wrong. 
4) Creative skill: This skill will teach one how to be genuinely enthusiastic in doing business. Ones approach may not likely work for all business, hence creative skill is vital to building lasting success and ensuring your service has an edge over your competitors.

5) Screw it, just do it skill: Finally, to succeed in business you must have the bravery to give it a go. Starting a business is a big risk. An entrepreneur needs resolve and conviction to overcome the early hurdles. Most start ups fail in the first few years, so a key ingredient of success is the ability to pick up and try again.

\section{CHARACTERISTICS OF ENTREPRENEUR}

An entrepreneur possesses a complex personality, certain personality characteristics that makes him quite different and most of these entrepreneurial traits can be further developed in an individual if they are present in him to some extent in latent form by well-structured training and development programmes. Some of the important characteristics attributable to successful entrepreneurs are listed below:

1. Self-confidence: Confidence, independence, individuality and optimism. They tend to believe strongly in themselves and their ability to achieve goals

2. Task - Result oriented: Need for achievement, profit oriented, persistence, determination, hard work, drive and initiative

3. Risk Taker: Risk taking, likes challenges

4. Leadership: Leadership behaviour, get along well with others, responsive to suggestions and criticisms

5. Originality: Innovative, creative, flexible, resourceful, versatile and knowledgeable.

6. Future oriented foresight and perceptive (Ajani and Ayelokan, 2010).

\section{IMPLICATIONS OF ENTREPRENEURIAL DEVELOPMENT ON YOUTH EMPOWERMENT}

Youth empowerment is an attitudinal, structural and cultural process whereby young people gain the ability, authority and agency to make decisions and implement change in their own lives and the lives of other people, including youths and adults. Youth empowerment is often addressed as a gateway to intergenerational equity, civil engagement and democracy building (Wikipedia, 2013).

Empowering young people means creating and supporting the enabling conditions under which young people can act on their own behalf, and on their own terms, rather than at the direction of others. Common Wealth of Nations opined that young people are empowered when they acknowledge that they have or can create choices in life, are aware of the implications of these choices, make an informed decision freely, take action based on that decision and accept responsibility for the consequences of these actions (Wikipedia, 2013). Taking a cue from the objectives of entrepreneurship education earlier mentioned as enunciated by Oborah (2006), it is easily deductible that entrepreneurship development will in no mean way create jobs which translate to youth empowerment.

Youth empowerment could be said to mean, the youths being able to eat when they are hungry, being able to meet their basic needs, have a shelter over their heads, ability to speak 
out in things of concern to them in the society, not being deprived in any ramification in life and ability to cater for their health needs whenever necessary.

In fact, entrepreneurship development reduce unemployment and poverty to the barest minimum especially to those who embrace the knowledge and skills inherent in it. Entrepreneurship education could be likened to the Laoche principle of teaching a child how to catch fish and not to give him fish when hungry. When the child is abreast with the rudiments of the expectation on him, it can now serve as a spring board on which he will attain self actualization in the hierarchy of needs theory.

\section{CONCLUSION}

It is obvious from the foregoing that we cannot simply prepare trainees or students for every situation they will face, but if we can give them skills they can use to deal with challenges they will encounter, we could have given them something of immense value (Christenson, 1996). The global economy today places premium on ability to continually update skills and knowledge.

Entrepreneurial development would produce an individual who can explore and exploit available resources and initiate economically rewarding business projects that could be a catalyst for reducing unemployment problem in the nation.

Also entrepreneurship education has been identified across the globe as a tool for generating suitable economy hence Isike and Ovekaemo (2008) maintains that no country can move forward technologically, industrially and economically without strongly developing enterprising skills which translates to reduction in unemployment.

\section{Recommendations}

Based on the foregoing the following recommendations are made:

1. The Educational authority in the country should review our curriculum to embrace the acquisition of entrepreneurial skills

2. Lectures, seminars and symposium should be organized for the youths on value reorientation as to dissuade them from get -rich- quick syndrome.

3. Notable and successful entrepreneurs should be invited to give talks from time to time to students at various tertiary institutions.

4. There should be eradication of corrupt practices among people in position of authority so that poverty reduction programmes introduced by the government can succeed.

5. Youths should as a matter of necessity understand themselves as it will help them to identify areas of their strengths and align with them. This will make them more focused in life as to evade unemployment.

6. Government should provide the necessary basic amenities and infrastructural facilities that will enable entrepreneurs to thrive in the country. 


\section{References}

[1] Ajani, S.T. and Ayelotan, O.I (2011). Entrepreneurship Skills Development in Business Education. Book of Readings, Association of Business Educators of Nigeria (ABEN) $1(11)$.

[2] Akpan, A.E. (2011). Gearing the National Economic Empowerment and Development Strategy Towards Sustainable National Development. Book of Readings, Association of Business Educators of Nigeria (ABEN) 1(11).

[3] Akpoveta, B.E. and Agbomah, D (2009). Entrepreneurship Development and Skill Acquisition Schemes as Tools for Youth Self-Employment, Economic Empowerment and National Development. Journal of Industrial and Technological Research.

[4] Atakpa, R.A (2011). Entrepreneurship Education: A Sine Qua-non in Business Education in Nigeria. Book of Readings, Association of Business Educators of Nigeria (ABEN) $1(11)$.

[5] Branson, C. (2010). Tips for Entrepreneurial Success. Sunday Punch, July, 18.

[6] Christenson, S. (1996). Keeping Taps on Youths. The Link College of Education and Human Resources, University of Minnesota.

[7] Damuchi, A.N (2011). Evaluation of Past Policy Measures for Solving Unemployment Problems. Lagos CBN Bullion Publication. 28.

[8] Gana, J.S.S (2008). Entrepreneurship. Kanada, Joefegan Associate Ltd.

[9] Garba, A.S. (2010). Refocusing Education System Towards Entrepreneurship Development in Nigeria: A Tool for Poverty Eradication. European Journal of Social Sciences is (1) Retired (2010 from www.eurojornals.com/ejssis-1-13.pdf.

[10] Hisrich, R.D and Peters, M.P. (2007) Entrepreneurship. $5^{\text {th }}$ Edition Singapore: McGraw-Hill Higher Education

[11] Igbo, C.A (2004). Entrepreneur Initiatives in Colleges of Education Programmes. Paper presented at the workshop on capacity Building for lecturers in Colleges of Education, $19^{\text {th }}-25^{\text {th }}$ Sept.

[12] Ihekwoaba, M.E. (2007). Entrepreneurship in Vocational and Technical Education. Lagos: Mukugamu Brothers Enterprises

[13] Iheonunekwu, S. (2003). Entrepreneurship Theory and Practice, Owerri; Crown Publishers Nig Ltd.

[14] Isike O. R., Ovekaemo E. C., Delta Business Education Journal 1(3) (2008) 113-118.

[15] Matsushita, M. (2008). State of Industrialization Forecloses Vision 20:2020 Attainment. Lagos Financial Standard 9(287).

[16] Norwegian Agency for Development Cooperation (2010). Technical and Vocational Education and Training.

http://www.norad.no/en/Thematic+areas/Education/from+ childhood-to-adulthoodtechnical + and + vocational+Education and + Training. 151129.CMS. Retrieved $(12 / 8 / 09)$.

[17] Nwagwu, J.U. (2004). Alleviating Poverty Through Vocational Education: The Nigerian Experience. Faculty of Education Imo State University, Owerri.

http:/www.gla.uk/centres cradall docs Botswana-papers N\VAG\vL paper-61.pdf Retired 23/9/2009.

[18] Oborah J. O., Business Education Journal 2(2) (2006) 34-38.

[19] Ojeaga, I.J. and Owolabi, J.I. (2011). Entrepreneurship Education as a Panacea for Reducing Unemployment and Poverty Among Business Education Graduates. Book of Readings, Association of Business Educators of Nigeria (ABEN) 1(11). 
[20] Oviawe J. I., Anarberokhai M. O., Technical and Vocational Education Journal 1(1) (2008) 57-65.

[21] Steinhoff, D. and Burges, J.F. (2003). Small Business Management. New York: McGraw-Hill International.

[22] Timmons, R. (2007) .New Ventures, Creation: A Guide to Small Business Development. New York: Appleton Century Craftsline.

[23] Wikipedia (2013) Youth Empowerment. Last modified on $12^{\text {th }}$ April, 2013.

[24] Tomáš Hes, Anna Poledňáková, International Letters of Social and Humanistic Sciences 2 (2013) 18-31.

[25] Mohsen Mehrara, Masoumeh zirak, International Letters of Social and Humanistic Sciences 2 (2013) 32-38.

[26] Taiwo Adewale Muritala, Ismail O. Fasanya, International Letters of Social and Humanistic Sciences 2 (2013) 39-50.

[27] Borowski A., International Letters of Social and Humanistic Sciences 3 (2013) 46-53.

[28] Borowski A., International Letters of Social and Humanistic Sciences 3 (2013) 69-74.

[29] Donovan A. McFarlane, International Letters of Social and Humanistic Sciences 4 (2013) 35-44.

[30] Rajesh K. Yadav, Nishant Dabhade, International Letters of Social and Humanistic Sciences 4 (2013) 49-69.

[31] Borowski A., International Letters of Social and Humanistic Sciences 4 (2013) 70-74.

[32] Paul Bukuluki, International Letters of Social and Humanistic Sciences 5 (2013) 27-44.

[33] Mohsen Mehrara, Maysam Musai, International Letters of Social and Humanistic Sciences 5 (2013) 55-62.

[34] Debiprasad Mukherjee, International Letters of Social and Humanistic Sciences 6 (2013) 41-48.

[35] Tomáš Hes, Alena Neradová, Karel Srnec, International Letters of Social and Humanistic Sciences 7 (2013) 55-75.

[36] Kinga Dziwańska, International Letters of Social and Humanistic Sciences 7 (2013) 96-112.

[37] Borowski A., International Letters of Social and Humanistic Sciences 7 (2013) 113-118.

[38] Mohsen Mehrara, Maysam Musai, International Letters of Social and Humanistic Sciences 8 (2013) 1-7.

[39] Tittenbrun J., International Letters of Social and Humanistic Sciences 11 (2013) 10-34.

[40] Mohsen Mehrara, Hamid Abrishami, Mostafa Boroujli, Mahan Amin, International Letters of Social and Humanistic Sciences 11 (2013) 76-83.

[41] Borowski A., International Letters of Social and Humanistic Sciences 11 (2013) 100-105.

[42] Morteza Amani, Mahmood Goodarzi, Hamze Ahamadian, International Letters of Social and Humanistic Sciences 1 (2014) 7-13.

[43] Seyed Mohammad Marandi, Hossein Pirnajmuddin, International Letters of Social and Humanistic Sciences 1 (2014) 14-27.

[44] Elias Olukorede Wahab, Chioma Joan Ikebudu, International Letters of Social and Humanistic Sciences 1 (2014) 28-42.

[45] Bahram Meihami, Zeinab Varmaghani, Hussein Meihami, International Letters of Social and Humanistic Sciences 1 (2014) 43-5.

[46] Francis Briggs, Elizabeth Desmond, International Letters of Social and Humanistic Sciences 1 (2014) 71-80. 
[47] Liverpool E. Onyije, Jacinta A. Opara, International Letters of Social and Humanistic Sciences 1 (2014) 81-87

[48] Sele Sylvester Ebisin, International Letters of Social and Humanistic Sciences 2 (2014) $1-9$.

[49] Tittenbrun J., International Letters of Social and Humanistic Sciences 2 (2014) 20-40.

[50] Borowski A., International Letters of Social and Humanistic Sciences 2 (2014) 110-121.

[51] Pawa Tersoo, International Letters of Social and Humanistic Sciences 3 (2014) 26-36.

[52] Rabi'u Muhammad Ishaq, International Letters of Social and Humanistic Sciences 3 (2014) 37-44.

[53] Adoga James Ada, International Letters of Social and Humanistic Sciences 3 (2014) 45-52.

[54] Bahram Meihami, Hussein Meihami, International Letters of Social and Humanistic Sciences 3 (2014) 80-91.

[55] Kabiru Ibrahim Yankuzo, International Letters of Social and Humanistic Sciences 4 (2014) 1-8.

[56] Onyike Maggaret Odu, International Letters of Social and Humanistic Sciences 4 (2014) 31-39.

[57] Uloma Charity Oguzor, International Letters of Social and Humanistic Sciences 4 (2014) 97-104.

[58] Okezie A. Ihugba, Alex Odii, A. C. Njoku, International Letters of Social and Humanistic Sciences 5 (2014) 21-34.

[59] Okezie A. Ihugba, Bankoli Bankong, N. C. Ebomuche, International Letters of Social and Humanistic Sciences 5 (2014) 92-113.

[60] Borowski A., International Letters of Social and Humanistic Sciences 6 (2013) 86-90.

[61] Borowski A., International Letters of Social and Humanistic Sciences 3 (2013) 69-74. 